\title{
REVITALISASI MANAJEMEN WAKAF SEBAGAI PENGGERAK EKONOMI MASYARAKAT
}

\author{
Zainal Arifin Munir \\ Dosen Fakultas Syariah IAIN Mataram \\ yanmu4all@yahoo.com
}

\begin{abstract}
Abstrak
Mobilize sectors of the society economy with waqf instrument is very rasional. According data compiled by the Ministry of Religious Affairs, the number of waqf land in Indonesia reached $2,686,536,656,68$ square meters or $268,653.67$ acres 366595 locations spread across an area Indonesia. With a large area, it will contribute to socio-economic empowerment if it is managed with proper and professional management. This is the most urgent matter to be addressed in the management of waqf is nadzir professionalism, because they are the key to successful management of endowments to be more focused, productive and strategic. As one of the sharia instruments, the management of waqf should be rightfully optimized for development the welfare of society.

Menggerakkan sektor ekonomi masyarakat dengan instrument wakaf adalah sangat rasional.Menurut data yang dihimpun Departemen Agama RI, jumlah tanah wakaf di Indonesia mencapai 2.686.536.656, 68 meter persegi atau 268.653,67 hektar yang tersebar di 366.595 lokasi di seluruh Indonesia. Dengan lahan seluas itu, tentunya akan sangat berkonstribusi dalam pemberdayaan social ekonomi jika dikelola dengan manajemen yang tepat dan profesional. Inilah hal yang paling urgen untuk dibenahi dalam pengelolaan wakaf adalah profesionalisme nadzir, karena mereka merupakan kunci keberhasilan pengelolaan wakaf agar lebih focus, produktif dan strategic. Sebagai salah satu instrument syariah, manajemen wakaf sudah seharusnya dioptimalkan pengelolaannya untuk peningkatan kesejahteraan masyarakat.
\end{abstract}

Kata Kunci: Wakaf, Manajemen, Ekonomi

Universalitas Islam menuntut terealisasinya syariat secara holistic. Islam hendaknya tidak hanya diposisikan sebagai faith tetapi juga sebagai manahij al hayah dalam mewujudkan maqashid al syariah yaitu maslahah. ${ }^{1}$ Sektor sosial

\footnotetext{
${ }^{1}$ Secara umum konsep maslahah yang paling mendasar diformulasikan oleh para fuqaha "mengambil manfaat dan menolak kemudaratan untuk memelihara tujuan-tujuan syara" adapun tujuan syara' yang paling utama dalam hukum Islam dikenal dengan al-masalih al khamsah, yaitu: (1) memelihara agama, (2) memelihara jiwa, (3) memelihara akal, (4) memelihara keturunan, dan 5) memelihara harta. Abu Ishaq al-Syathibi, AlMuwafagat fi Ushul al-Syari'ah, (Beirut: Dar al-Ma'rifah,
}

dan ekonomi yang merupakan sektor yang paling berpengaruh dalam kehidupan manusia khususnya, sehingga sentuhan"islamisasi" rasanya sudah mendesak untuk diterapkan agar aktivitas muamalah/ekonomi lebih kontributif dalam segala lini.

Syariah pada dasarnya sudah menawarkan beberapa instrument alternatif dalam pemberdayaan social ekonomi seperti zakat, infaq, shodaqoh dan wakaf. Zakat dan wakaf ${ }^{2}$

1973), h. 8-12

${ }^{2}$ Kata wakaf atau waqf berasal dari bahasa 
merupakan instrumen ekonomi Islam yang perlu dikembangkan untuk membiayai kepentingan umat terutama dalam pengembangan social dan ekonomi umat. Pengelolaan wakaf di Indonesia masih bersifat statis dan belum bernilai ekonomis dan produktif, karena pemanfaatan wakaf masih sebatas hal-hal yang bersifat fisik, seperti gedung, tanah atau benda yang tahan lama.

Menurut data yang dihimpun Departemen Agama RI, jumlah tanah wakaf di Indonesia mencapai 2.686.536.656, 68 meter persegi (dua milyar enam ratus delapan puluh enam juta lima ratus tiga puluh enam ribu enam ratus lima puluh enam koma enam puluh delapan meter persegi) atau 268.653,67 hektar (dua ratus enam puluh delapan ribu enam ratus lima puluh tiga koma enam tujuh hektar) yang tersebar di 366.595 lokasi di seluruh Indonesia. ${ }^{3}$

Dengan lahan seluas itu, tentunya akan sangat konstributif dalam pemberdayaan social ekonomi jika di dapat dikelola dengan manajemen yang tepat dan professional. Wakaf tidak hanya hanya bertujuan menyediakan berbagai sarana ibadah dan sosial, tetapi juga memiliki potensi ekonomi yang sangat tinggi. Sehingga wakaf perlu ditingkatkan kemanfaatannya sesuai dengan prinsip-prinsip syariah.

Sebagai contoh, cukup banyak tanah wakaf yang di atasnya dibangun masjid atau

Arab yang berasal dari akar kata روقف : روقف, jamak berarti menahan, berhenti, diam di tempat atau berdiri. Kata waqafa-yaqifu-waqfan semakna dengan kata habasa-yahbisu-tahbisan maknanya terhalang untuk menggunakan. Kata waqf dalam bahasa Arab mengandung makna: menahan, menahan harta untuk diwakafkan, tidak dipindahmilikkan. Lihat Wahbah Zuhaili (1985), Al-Figh al-Islamiy wa 'Adillatuhu, (Mesir: Dar al-Fikr al-Mu'ashir), h. 7599.

wakat menurut istilah, Undang-Undang Nomor 41 Tahun 2004 tentang wakaf yang menjadi payung hukum yang lebih kuat berskala nasional, mendefiniskan bahwa:

"Wakaf adalah perbuatan hukum wakif untuk memisahkan dan/atau menyerahkan sebagian harta benda miliknya untuk dimanfaatkan selamanya atau untuk jangka waktu tertentu sesuai dengan kepentingannya guna keperluan ibadah dan/atau kesejahteraan umum menurut syariah"

${ }^{3}$ Badan Wakaf Indonesia, Database dan Potensi Wakaf, publikasi di http://bwi.or.id/index. Akses 24 Februari 2011. musholla, sedang sisa tanahnya yang masih luas bisa dibangun gedung pertemuan untuk disewakan kepada masyarakat umum. Hasil penyewaan gedung tersebut dapat digunakan untk memelihara masjid atau misalnya ada tanah wakaf yang terletak cukup strategis dalam usaha bisa di bangun ruko atau gedung perkantoran yang bisa dikelola sendiri atau disewakan dan hasilnya bisa untuk perawatan gedung wakaf yang telah ada atau untuk menunjang kegiatan atau pemberdayaan ekonomi lemah yang ada di sekitarnya.

Universitas Al Azhar, dengan pemberdayaan wakaf telah mampu membiayai operasional pendidikan dan pembiayaan mahasiswanya selama berabad-abad tanpa tergantung pada pemerintah. ${ }^{4}$ Universitas Al-Azhar selaku nadzir hanya mengambil hasilnya untuk keperluan pendidikan. Bahkan dalam sejarah peradaban Islam, wakaf telah memberikan konstribusi yang besar pembangunan ekonomi masyarakat, di antaranya: ${ }^{5}$ (a) Hampir 75\% seluruh lahan yang dapat ditanami di Daulah Khilafah Turki Usmani merupakan tanah wakaf; (b) Setengah (50\%) dari lahan di Aljazair, pada masa penjajahan Perancis pada pertengahan abad ke 19 merupakan tanah wakaf; (c) Pada periode yang sama, $33 \%$ Tanah di Tunisia merupakan tanah wakaf; (d) Di Mesir sampai dengan tahun 1949, 12,5 persen lahan pertanian adalah tanah wakaf; (e) Pada Tahun 1930 di Iran, sekitar 30 persen dari lahan yang ditanami adalah lahan wakaf.

Berdasarkan realitas sejarah tersebut wakaf merupakan instrumen ekonomi Islam yang perlu dikembangkan untuk membiayai kepentingan umat terutama dalam pengembangan social dan ekonomi umat. Di Indonesia, wakaf telah dikenal dan dilaksanakan oleh umat Islam sejak agama Islam masuk di Indonesia. Sebagai suatu lembaga Islam, wakaf telah menjadi salah satu penunjang perkembangan masyarakat Islam. Salah satu bentuk wakaf yang banyak dilaksanakan di Indonesia adalah dalam bentuk tanah. Kebiasaan berwakaf sebenarnya telah

\footnotetext{
${ }^{4}$ Republika, 27 Oktober 2011

${ }^{5}$ M.A, Mannan, Sertifikat Wakaf Tunai, (Jakarta; UI Press, 2001), h. 13
} 
berkembang sedemikian rupa di kalangan umat Islam di Indonesia, walaupun hasilnya belum maksimal seperti yang diharapkan. Kenyataan ini memerlukan penanganan profesional untuk mengembangkan potensi wakaf sebagai penunjang dakwah Islamiyah. ${ }^{6}$

Dalam perspektif sosio ekonomi, wakaf yang ada, belum berperan dalam menanggulangi permasalahan umat, hal ini disebabkan wakaf kurang optimal dalam pengelolalaannya. ${ }^{7}$ Idealnya, wakaf dapat dikelola secara produktif dan dikembangkan menjadi lembaga Islam yang dapat meningkatkan kesejahteraan masyarakat. Realnya, bersama dengan zakat, wakaf dapat menjadi instrumen dalam pengentasan kemiskinan. ${ }^{8}$

Lahirnya Undang-Undang Republik Indonesia Nomor 41 Tahun 2004 tentang Wakaf diarahkan untuk memberdayakan wakaf yang merupakan salah satu instrumen dalam membangun kehidupan sosial ekonomi umat Islam. Kehadiran Undang-undang wakaf ini menjadi momentum pemberdayaan wakaf secara produktif, sebab di dalamnya terkandung pemahaman yang komprehensif dan pola manajemen pemberdayaan potensi wakaf secara modern.

Sebagai instrument ekonomi Islam yang belum popular, masyarakat muslim di Indonesia belum memiliki tradisi yang kuat untuk memaksimalkan pengelolaan wakaf sebagai penggerak ekonomi masyarakat. Pentingnya pengembangan wakaf di Indonesia tentunya berimplikasi pada bagaimana pengelolaan wakaf yang optimal dalam memberikan pemanfaatan bagi masyarakat. Untuk diperlukan manajemen pengelolaan wakaf yang profesional, amanah, transparan, dan accountable.

\section{Konsepsi Wakaf}

Kata wakaf atau waqf berasal dari bahasa

${ }^{6}$ Abdul Ghofur Anshori, Hukum dan Praktik Perwakafan di Indonesia, (Yogyakarta: Pilar Media, 2005), h. 2

${ }^{7}$ Uswatun Hasanah dalam Kata Pengantar Buku Munndzir Qahaf, Manajemen Wakaf Produktif, (Jakarta: Khalifa, 2005), h. xv

${ }^{8}$ Sayyid Sabiq, Figh Sunnah, (Beirut: Dar alFikri,1980)
Arab yang berasal dari akar kata وقف, jamak: اوقاف, berarti menahan, berhenti, diam di tempat atau berdiri. Kata waqafa-yaqifu-waqfan semakna dengan kata habasa-yahbisu-tahbisan maknanya terhalang untuk menggunakan. Kata waqf dalam bahasa Arab mengandung makna: menahan, menahan harta untuk diwakafkan, tidak dipindahmilikkan. ${ }^{9}$

Dalam terminologi Hukum Islam, kata tersebut didefinisikan sebagai suatu tindakan penahanan dari penggunaan dan penyerahan aset di mana seseorang dapat memanfaatkan atau menggunakan hasilnya untuk tujuan amal, sepanjang barang tersebut masih ada. ${ }^{10}$ Sumber lain menyatakan bahwa wakaf berarti menahan tindakan hukum. Persoalan wakaf adalah persoalan pemindahan hak milik yang dimanfaatkan untuk kepentingan umum. ${ }^{11}$

Dari segi fiqh, para fuqaha berbeda pendapat dapat mendefinisikan wakaf, perbedaan itu tergantung pada mazhab yang mereka anut, berikut penulis uraiakan pengertian wakaf menurut ulama fiqh: ${ }^{12}$

1. Menurut Mazhab Syafi'iyah

a. Imam Nawasi mendefinisikan wakaf dengan: "Menahan harta yang dapat diambil manfaatnya bukan untuk dirinya, sementara benda itu tetap ada dan digunakan manfaatnya untuk kebaikan dan mendekatkan diri kepada Allah."

b. Ibnu Hajar Al Haitami dan Syaikh Umairah mendefinisikan wakaf dengan: "Menahan harta yang bisa dimanfaatkan dengan menjaga keutuhan harta tersebut dengan memutuskan kepemilikan harta tersebut dari pemiliknya untuk hal yang bolehkan."

c. Syaikh Syihabuddin Al Qalyubi, mendefinisikan: "Menahan harta untuk dimanfaatkan, dalam hal yang dibolehkan dan menjaga keutuhan harta."

${ }^{9}$ Wahbah Zuhaili, Al-Figh al-Islamiy wa 'Adillatuhu, (Mesir: Dar al-Fikr al-Mu'ashir, 1985), h. 7599.

${ }^{10}$ M. A. Mannan, Sertifikat Wakaf Tunai (Jakarta: CiBER bekerjasama dengan PKTTI-UI, 2005), h. 29

${ }^{11}$ Abdul Azis Dahlan, Ensiklopedi Hukum Islam (Jakarta: PT. Ichtiar Baru Van Hoeve, 2003), h. 190

${ }^{12}$ Muhammad Abid Abdullah Al Kabisi, Hukum Wakaf, (Jakarta: Penerbit Iman, 2004), h. 40-62. 


\section{Menurut Mazhab Hanafiyah}

a. ImamSyarkhasi mendefinsikan: “Menahan harta dari jangkauan (kepemilikan) orang lain."

b. Al-Murghinany, mendefinisikan:“Menahan harta dibawah tangan pemiliknya, disertai pemberian manfaat sebagai sedekah."

\section{Menurut Mazhab Malikiyah}

Ibnu Arafah mendefinisikan wakaf dengan: "Memberikan manfaat sesuatu, pada batas waktu keberadaannya bersamaan dengan tetapnya wakaf dalam kepemilikan si pemberli meski hanya perkiraan."

Menurut peraturan perundang-undangan di Indonesia, rumusan definisi wakaf adalah: (1) Peraturan Pemerintah Nomor 28 tahun 1977, wakaf adalah perbuatan hukum seseorang atau badan hukum yang memisahkan sebagian dari harta kekayaannya yang berupa tanah milik dan kelembagaannya untuk selamalamanya untuk kepentingan atau keperluan umat lainnya sesuai ajaran Islam; (2) Kompilasi Hukum Islam (KHI), wakaf adalah perbuatan hukum seseorang atau kelompok orang atau badan hukum yang memisahkan sebagian dari benda miliknya dan kelembagaannya untuk selama-lamanya guna kepentingan ibadah atau keperluan umum lainnya sesuai ajaran Islam; (3) Undang-Undang Wakaf Nomor 41 Tahun 2004 dinyatakan bahwa wakaf adalah perbuatan hukum wakif untuk memisahkan dan/atau menyerahkan sebagian harta benda miliknya untuk dimanfaatkan selamanya atau untuk jangka waktu tertentu sesuai dengan kepentingannya guna keperluan ibadah dan atau kesejahteraan umum menurut syariah.

\section{Landasan Hukum Wakaf}

1. Al-Qur'an

Dalam Al-Qur'an terdapat beberapa ayat yang menganjurkan untuk menunaikan wakaf, beberapa diantaranya adalah (QS. Al-Imran[3]: 92) dan (QS.Al-Baqarah[2]: 267):

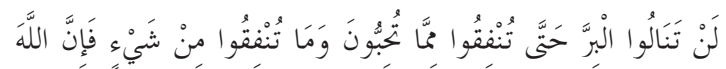

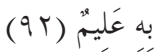

Artinya: Kamu sekali-kali tidak sampai kepada kebajikan (yang sempurna), sebelum kamu menafkahkan sehahagian harta yang kamu cintai. Dan apa saja yang kamu nafkahkan, maka sesungguhnya Allah mengetahuinya. ${ }^{13}$

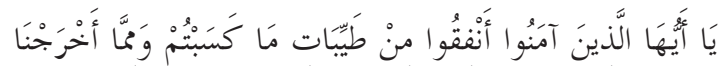

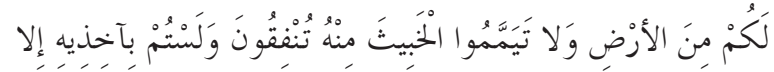

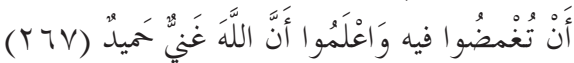

Artinya: Hai orang-orang yang beriman, nafkahkanlah (di jalan Allah) sebagian dari hasil usahamu yang baik-baik dan sebagian dari apa yang kami keluarkan dari bumi untuk kamu, dan janganlah kamu memilih yang buruk-buruk lalu kamu menafkahkan daripadanya, padahal kamu sendiri tidak mau mengambilnya melainkan dengan memincingkan mata terhadapnya, dan ketahuilah bahwa Allah Maha Kaya lagi Maha Terpuji.

\section{Hadits}

Para ahli hadis dan kebanyakan ahli fiqh mengidentifikasi bahwa wakaf termasuk sadaqah jariyah, Dalam hadis tersebut bahwa sadaqah jariyah direalisasikan dalam bentuk wakaf yang pahalanya mengalir terus menerus kepada si wakif.

اذاماتالانسانانقطعنهعملهالامنثلاثة, صدقةجاريةأو علمينتفعبه

$$
\text { أوولدصالحيدعوله }
$$

Artinya: Jika manusia mati, maka terputuslah amalannya, kecuali tiga perkara: sedekah jariyah, ilmu yang bermanfaat dan anak saleh yang mendoakannya. ${ }^{14}$

Hadis yang lebih tegas menggambarkan dianjurkannya wakaf, yaitu hadis riwayat Ibn Umar tentang tanah khairbar. Dalam suatu riwayat dinyatakan bahwa: "Sahabat Umar ra memperoleh sebidang tanah di Khaibar, kemudian menghadap kepada Rasulullah untuk memohon petunjuk. Umar berkata: ya Rasulullah, saya mendapatkan sebidang tanah di Khaibar, saya belum pernah mendapatkan harta sebaik itu, maka apakah yang engkau ${ }^{13}$ (QS. Al-Imran[3]: 92)

${ }^{14}$ Muslim Ibn al-Hujjaj, Al-Jami' as-Sahih, (Beirut: Dar al-Fikr, tt), V: 73 “Bab Mā Yulhaqu al-Insān min as-Sawab Ba'da wa Fatihi. 
perintahkan kepadaku? Rasulullah menjawab: bila kamu suka, kamu tahan (pokoknya) tanah itu, dan kamu sedekahkan (hasilnya). Kemudian Umar melakukan shadaqah, tidak dijual, tidak dihibahkan dan tidak pula diwariskan. Ibnu Umar berkata: Umar menyedekahkankannya kepada orang fakir, kaum kerabat, bidak belian, sabilillah, ibn sabil dan tamu. Dan tidak dilarang bagi orang yang menguasai tanah wakaf itu (mengurus) untuk makan dari hasilnya dengan cara baik (sepantasnya) atau makan dengan tidak bermaksud menumpuk harta."15

\section{Hukum Positif di Indonesia}

Di Indonesia sampai sekarang terdapat berbagai regulasi yang mengatur perwakafan tanah milik. Seperti dimuat dalam buku Himpunan Peraturan Perundang-undangan Perwakafan Tanah yang diterbitkan oleh Departemen Agama RI, maka dapat dilakukan inventarisasi sebagai berikut: ${ }^{16}$

1. Undang-Undang Nomor 5 Tahun 1960 tentang Peraturan Dasar Pokok-Pokok Agraria (UUPA). Dalam undang-undang tersebut masalah wakaf dapat kita ketahui pada Pasal 5, Pasal 14 Ayat 1 dan Pasal 49 yang memuat rumusan sebagai berikut:

a. Pasal 5 UUPA menyatakan bahwa hukum agraria yang berlaku atas bumi, air dan ruang angkasa ialah hukum adat, sepanjang tidak bertentangan dengan kepentingan nasional dan negara. Dalam pasal ini jelaslah bahwa hukum adat lah yang menjadi dasar hukum agraria Indonesia, yaitu hukum Indonesia asli yang tidak tertulis dalam bentuk perundangundangan Republik Indonesia.

b. Pasal 14 Ayat 1 menyatakan bahwa pemerintah dalam rangka sosialisme Indonesia, membuat suatu rencana umum mengenai persediaan, peruntukkan dan

${ }^{15}$ Muhammad ibn al-Bukhari, Shahih al-Bukhari (Beirut Dar al-Fikr, 1981 M/1401 H), III: 185, “Kitab asy-Syurūt fī al-Wakaf." Hadis riyawat Bukhari dari Qutaibah ibn Sa'ad dari Muhammad ibn Abdullah alAnshari dari ibn 'Aun dari Nafi' dari ibn 'Umar Hadis ini sanadnya muttasil

${ }^{16}$ Muhammad Daud Ali, Sistem Perekonomian Islam, Zakat dan Wakaf, (Jakarta: UI Press, 1988), h. 83 penggunaan bumi, air, dan ruang angkasa serta kekayaan alam yang terkandung di dalamnya untuk keperluan peribadatan dan keperluan suci lainnya sesuai dengan dasar Ketuhanan Yang Maha Esa.

c. Pasal 49 menyatakan bahwa hak milik tanahtanah badan keagamaan dan sosial sepanjang dipergunakan untuk usaha dalam bidang keagamaan sosial, diakui dan dilindungi. Badan-badan tersebut dijamin akan memperoleh tanah yang cukup untuk bangunan dan usahanya dalam bidang keagamaan dan sosial. Pasal ini memberikan ketegasan bahwa persoalan perwakafan tanah milik dilindungi dan diatur dengan Peraturan Pemerintah.

2. Undang-Undang Nomor 41 Tahun 2004 tentang Wakaf. Melalui regulasi tersebut, berarti payung hukum tentang wakaf yang secara luas telah dijabarkan dalam bentuk undangundang. Undang-undang ini merupakan pengembangan dan penyempurnaan terhadap materi perwakafan yang ada sebelumnya. Undang-undang wakaf telah memuat ketentuan yang integral dan lengkap untuk memberikan kepastian hukum dalam pelaksanaan perwakafan. Dalam hal ini tentu bukan hanya berlaku untuk wakaf benda tidak bergerak, tetapi juga wakaf benda bergerak, termasuk pengelolaan dan pengembangan harta benda wakaf.

3. Peraturan Pemerintah Nomor 42 Tahun 2006 tentang Pelaksanaan Undang-Undang Nomor 41 Tahun 2004 tentang Wakaf. Pemberlakuan peraturan pemerintah tersebut merupakan sebagai penjelasan dalam pelaksanaan ketentuan pasal-pasal dalam undang-undang wakaf yang tertuang pada delapan pasal, yaitu Pasal 14 (tentang Nazhir), Pasal 21 (akta ikrar wakaf), Pasal 31 (wakaf benda bergerak berupa uang), Pasal 39 (PPAIW, tatacara pendaftaran dan pengumuman harta benda wakaf), Pasal 41 (perubahan status harta benda wakaf), Pasal 46 (pengelolaan dan pengembangan harta benda wakaf), Pasal 66 (pembinaan 
dan pengawasan Nazhir oleh Menteri dan Badan Wakaf Indonesia), dan Pasal 68 (sanksi administratif).

4. Peraturan Pemerintah Nomor 28 Tahun 1977 tentang Perwakafan Tanah Milik. Peraturan pemerintah ini merupakan payung hukum pertama yang secara lengkap menjelaskan tentang perwakafan tanah di Indonesia. Pemberlakuan peraturan ini tentu telah memberikan kepastian hukum secara jelas dalam pelaksanaan perwakafan tanah di Indonesia.

5. Instruksi Presiden (Inpres) Nomor 1 Tahun 1991 Tentang Kompilasi Hukum Islam. Inpres RI Nomor 1 Tahun 1991 berisi perintah kepada Menteri Agama RI dalam rangka penyebarluaskan Kompilasi Hukum Islam (KHI). Dalam beberapa hal, Hukum Perwakafan dalam Kompilasi Hukum Islam (KHI) merupakan pengembangan dan penyempurnaan pengaturan perwakafan sesuai dengan hukum Islam. Beberapa ketentuan perwakafan menurut KHI yang merupakan pengembangan dan penyempurnaan terhadap materi perwakafan yang ada pada regulasi sebelumnya, antara lain tentang: obyek wakaf, sumpah Nazhir, jumlah Nazhir, perubahan benda wakaf, pengawasan Nazhir, dan peranan Majelis Ulama dan Camat.

Dalam pengelolaan wakaf sangat penting untuk memperhatikan asas-asas yang mendasar, yaitu:

1. Asas Keabadian Manfaat. Suatu benda (wakaf) itu bisa dikategorikan memiliki nilai keabadian manfaat apabila ada empat hal dimana benda wakaf (shadaqah jariyyah) akan mendapatkan nilai pahala yang terus mengalir karena kemanfaatannya, yaitu: (a) Benda tersebut dapat dimanfaatkan (digunakan) oleh orang banyak; (b) Benda wakaf memberikan nilai yang lebih nyata kepada para wakif itu sendiri. Secara material, para wakif berhak (boleh) memanfaatkan benda wakaf tersebut sebagaimana juga berlaku bagi para penerima wakaf lainnya; (c) Manfaat immaterial benda wakaf melebihi manfaat materialnya. Atau bisa dibahasakan sederhana dengan bahwa nilai ekstrinsik benda wakaf melebihi nilai intrinsiknya; $(\mathrm{d})$ Dan yang paling penting dari benda wakaf itu sendiri adalah tidak menjadikan atau mengarahkan kepada bahaya (madharat) bagi orang lain (penerima wakaf) dan juga wakif sendiri.

2. Asas Pertanggung Jawaban. Pertanggungjawaban merupakan asas paradigma baru wakaf. Sebagai sebuah ajaran yang memiliki dimensi ilahiyyah dan insaniyyah, wakaf harus dapat dipertanggungjawabkan baik di dunia maupun di akhirat kelak.

3. Asas ProfesionalismeManajemen. Manajemen pengelolaan menempati pada posisi paling urgen dalam dunia perwakafan. Karena yang paling menentukan adalah ketika benda wakaf itu memiliki nilai manfaat, meskipun tidak tergantung pada pola pengelolaan bagus atau buruk. Kalau pengelolaan benda-benda wakaf selama ini hanya dikelola "seada-adanya" dengan menggunakan "manajemen kepercayaan" dan sentralisme kepemimpinan yang mengesampingkan aspek pengawasan, maka dalam pengelolaan wakaf secara modern harus menonjolkan system manajemen yang lebih profesional. Dan asas profesionalitas manajemen ini harusnya dijadikan semangat pengelolaan benda wakaf dalam rangka mengambil kemanfaatan yang lebih luas dan lebih nyata untuk kepentingan masyarakat banyak (kebajikan).

Dalam sebuah teori manajemen modern biasa disebut dengan istilah TMQ (Total Quality Management) dengan kerangka teori yang utuh hanya mengerucut kepada empat hal, yaitu: ${ }^{17}$

1. Amanah (dapat dipercaya). Secara umum, pola manajemen dianggap profesional jika seluruh sistem yang digunakan dapat dipercaya, baik input atau output-nya. Input dalam sebuah pengelolaan bisa dilihat dari

${ }^{17}$ Direktorat Pemberdayaan Wakaf, Direktorat Jenderal Bimbingan Masyarakat Islam, Paradigma Baru,Wakaf, 2006, h. 82 
Sumber Daya Manusianya (SDM), dalam hal wakaf adalah pihak nazhir yaitu: (a) Memiliki standar pendidikan yang tinggi (terdidik) dan standar moralitas yang unggul, sehingga seluruh proses yang dilakukan dapat menghasilkan produk yang baik dan tidak merugikan orang lain; (b) Memiliki ketrampilan lebih, sehingga dapat memberikan produk yang berkualitas dan memiliki kelebihan dibandingkan dengan yang lain; (c) Adanya pembagian kerja (Job Description) yang jelas, sehingga tidak akan terjadi tumpang tindih wewenang, peran dan tanggung jawab; (d) Adanya standar hak dan kewajiban. Tidak ada ketimpangan antara hak dan kewajiban setiap masing-masing pihak yang terlibat dalam sebuah pengelolaan manajemen; (e) Adanya standar operasional yang jelas dan terarah, sehingga tidak akan terjadi kepincangan manajemen.

2. Shiddiq (jujur) adalah sifat mendasar, baik yang terkait dengan kepribadian SDMnya maupun bentuk program yang ditawarkan sehingga konsumen atau masyarakat merasa tidak dimanfaatkan secara sepihak.

3. Fathanah (cerdas /brillian). Kecerdasan sangat diperlukan untuk menciptakan produk (program) yang bisa diterima oleh pasar (masyarakat) dengan menawarkan berbagai harapan yang baik dan maju.

4. Tabligh (menyampaikan informasi yang benar/ transparan). Sebenarnya konsep tabligh ini lebih kepada kemauan dan kemampuan menyampaikan segala informasi yang baik dan benar. Dalam manajemen, penyebarluasan informasi yang baik dan jujur sangat terkait dengan pola pemasaran dan pelaporan keuangan. Pemasaran sebuah produk harus disampaikan secara jujur, tidak menipu atau membodohi masyarakat.

Sedangkan, potret kepemimpinan manajemen yang baik dalam lembaga kenazhiran bisa dilihat dari tiga aspek, yaitu: (1) Transparansi. Dalam kepemimpinan manajemen profesional, transparansi menjadi ciri utama yang harus dilakukan oleh seorang pemimpin. Ketika aspek transparansi sudah ditinggalkan, maka kepemimpinan tidak akan berjalan dengan baik, bahkan membuka peluang terjadinya penyelewengan yang tak terkendali. Transparansi adalah aspek penting yang tak terpisahkan dalam rangkaian kepemimpinan yang diajarkan oleh nilai-nilai Islam; (2) Public accountability (pertanggungjawaban umum). Pertanggungjawaban umum merupakan wujud dari pelaksanaan sifat amanah (kepercayaan) dan shidiq (kejujuran). Karena kepercayaan dan kejujuran memang harus dipertanggungjawabkan baik di dunia maupun di akhirat kelak; (3) Aspiratif (mau mendengar dan mengakomodasi seluruh dinamika lembaga kenazhiran). Seorang nazhir yang dipercaya mengelola harta milik umum harus mendorong terjadinya sistem sosial yang melibatkan partisipasi banyak kalangan. Partisipasi perlu dilakukan untuk menghindari terjadinya pola pengambilan keputusan secara sepihak oleh kalangan elit kepemimpinan.

\section{Wakaf dan Keadilan Sosial Ekonomi}

Pemberdayaan wakaf sangat terkait erat dengan upaya menciptakan keadilan social ekonomi. Konsepsi keadilan sosial ekonomi yang Islami mempunyai ciri khas dari konsep ekonomi yang lain, diantaranya: (1) Keadilan sosial dilandasi prinsip keimanan yaitu bahwa semua orang yang ada di alam semesta adalah milik Allah.Manusia sebagai khalifah Allah dan sesuai dengan fitrahnya yang teomorfis ia dianugerahkan pemilikan sebagai karuniaNya; (2) Menggalakan sistem pendistribusian kembali pendapatan yang sifatnya built in, yang lebih diefektifkan lagi dengan mengaitkannya pada ridha Allah; (3) Keadilan sosial dalam Islam berakar pada moral. Implikasinya secara otomatis mendorong kewajiban untuk berbuat adil dan saling membantu.

Konsep keadilan sosial yang dianut oleh Islam juga menjadi asas paradigma baru wakaf, yaitu jika kita mewakafkan sebagian harta tidak tertuju pada aspek kedermawanan seseorang belaka, tetapi dengan sikap tersebut mengandung sisi penegakan keadilan sosial 
yang lebih merata. Keadilan merupakan asas fundamental dalam ajaran Islam, karenanya untuk mencapai keadilan tersebut wakaf harus dikelola secara profesional agar tidak menjadi tumpukan-tumpukan harta yang tidak memberi manfaat (maslahah) kepada masyarakat umum.

Terwujudnya maslahah adalah salah satu tujuan syariah. Mashlahah merupakan esensi dari kebijakan-kebijakan syariah (siyasah syar 'iyyah) dalam merespon dinamika sosial, politik, dan ekonomi. Di bidang ekonomi, kemaslahatan dirasa paling urgen karena Ekonomi telah menjadi standar kehidupan individu dan kolektif suatu negara-bangsa. Keunggulan suatu negara diukur berdasarkan tingkat kemajuan ekonominya. Oleh karena itu pengembangan sektor ekonomi adalah mutlak menjadi prioritas untuk dikembangkan dalam bingkai syariah untuk mewujudkan maslahah.

Zakat dan wakaf merupakan nilai instrumental sistem ekonomi Islam. Kedua lembaga ini merupakan sarana yang sangat erat hubungannya dengan kepemilikan. Disamping itu, kepemilikan selain menjadi dasar sistem ekonomi Islam, ia juga menyangkut hubungan manusia dengan benda atau harta kekayaan yang dimilikinya, yaitu mulai dari bagaimana cara memperolehnya, fungsi hak kepemilikan, dan cara memanfaatkannya.

Wakaf merupakan sarana utama dalam pendistribusian asset/kekayaan umat dan bersifat publik. Melalui wakaf diharapkan sumbersumber ekonomi tidak hanya terkonsentrasi pada orang-orang kaya saja, tapi juga memungkinkan terdistribusi kepada sebagian kalangan yang sangat membutuhkannya. Dalam Islam wakaf merupakan doktrin agama, sedangkan dalam perekonomian perwakafan merupakan sarana yang signifikan dalam mewujudkan kesejahteraan. Dengan demikian, kehidupan ekonomi dalam Islam merupakan bagian penting dari ibadah.

Menurut Monzer Khaf, wakaf dapat dibagi menjadi tiga, yaitu wakaf keagamaan, wakaf philanthropic, dan wakaf family atau wakaf keluarga. Wakaf keagamaan biasanya diperuntukkan untuk kegiatan keagamaan seperti mesjid. Mesjid Quba di Madinah merupakan salah satu contoh wakaf keagamaan. Wakaf philantropi antara lain layanan kesehatan, pendidikan, dan sejumlah fasilitas umum lainnya. Sedangkan wakaf keluarga biasanya lebih ditujukan sebagai jaminan untuk kelangsungan hidup dan kesejahteraan dari keturunan yang ditinggalkan. ${ }^{18}$

Khususnya di Indonesia, selama ini wakaf yang berkembang lebih banyak ke jenis wakaf yang pertama, yaitu wakaf keagamaan. Hal ini dapat diketahui dari data yang ada di Kementerian Agama yang menunjukkan bahwa selama ini perkembangan wakaf di Indonesia sampai dengan September 2001 jumlah seluruh tanah wakaf di Indonesia sebanyak 358.791 dengan luas 818.742.341,86 $\mathrm{M}^{2} .{ }^{19}$ Wakafwakaf ini kebanyakan dipergunakan untuk pembangunan masjid, musholla, sekolah, panti asuhan, dan makam. Dari data tersebut terlihat bahwa pengembangan wakaf selama ini masih terbatas pada wakaf yang sifatnya tidak bergerak dan tahan lama. Sehingga wakaf jenis ini tidak memberikan kontribusi secara langsung kepada masyarakat.

Di luar negeri, wakaf uang sudah lama dipraktikkan. Misalnya di Mesir, Universitas Al Azhar menjalankan aktivitasnya dengan menggunakan dana wakaf. Universitas tersebut mengelola gudang atau perusahaan di Terusan Suez. Universitas Al Azhar selaku nadzir atau pengelola wakaf hanya mengambil hasilnya untuk keperluan pendidikan. Di Qatar dan Kuwait, dana wakaf uang sudah berbentuk bangunan perkantoran. Areal tersebut disewakan dan hasilnya digunakan untuk kegiatan umat Islam.

Di Sudan, eksperimen mmanajemen wakaf dimulai pada tahun 1987 dengan kembali mengatur manajemen wakaf dengan Hama badan wakaf Islam untuk bekerja tanpa ada keterikatakn secara biroktratis dengan ${ }^{18}$ Monzer Kahf, Waqf and Its Sociopolitical Aspects, lihat www.kahf.net/papers.html

${ }^{19}$ Seperti dikutip Agustianto, Wakaf Tunai Dalam Hukum Positif dan Prospek Pemberdayaan Ekonomi Ssyari'ah, Makalah 
kementrian wakaf. Badan wakaf ini telah diberi wewenang yang lugas dalam memanaj dan melaksanakan semua tugas yang berhubungan dengan wakaf yang tidak diketahui akte dan syarat-syarat wakifnya.

Di Kuwait, Kementrian Wakaf melakukan penertiban semua manajemen wakaf yang ada di Kuwait dalam bentuk yang hamper sama dengan spa yang dilakukan di Sudan. Pada tahun 1993, kementerian wakaf sengaja membentuk semacam persekutuan wakaf di Kuwait untuk menanggung semua beban wakaf, baik itu wakaf lama maupun mendorong terbentuknya wakaf barn. Ada dua hal yang dilakukan, yaitu membentuk manajemen investasi harta wakaf danmanajemen harta wakaf pada bagian wakaf. ${ }^{20}$

Untuk kasus di Indonesia, selama ini wakaf lebih diarahkan ke lembaga keagamaan dan pendidikan. Lembaga pendidikan yang menggunakan wakaf sebagai penyangga dana operasional mereka, berapa diantaranya adalah Universitas Islam Indonesia di Yogyakarta, Universitas Islam Sumatera Utara di Medan dan Pondok Modern Gontor. Lembaga-lembaga tersebut bergerak di bidang pendidikan, untuk dapat memberikan konstribusi yang signifikan dibidang ekonomi tentu tidak instan.

Untuk memberdayakan wakaf secara produktif ada tiga filosofi dasar yang harus diperhatikan. Pertama, pola manajemennya harus dalam bingkai "proyek yang terintegrasi" dimana dana wakaf akan dialokasikan untuk program - program pemberdayaan dengan segala macam biaya yang terangkum didalamnya. Kedua, asas kesejahteraan nadzir yang berarti kita menjadikan nadzir sebagai profesi yang memberikan harapan kepada lulusan terbaik umat dan profesi yang memberikan kesejahteraan, bukan saja diakhirat tetapi juga di dunia. Seperti di Turki, badan pengelola wakaf mendapatkan alokasi $5 \%$ dari net income wakaf begitu juga dengan Kantor Administrasi Wakaf Bangladesh, dan The Central Waqf Council India mendapatkan alokasi sekitar $6 \%$. Ketiga, asas transparansi dan accountability. Badan

\footnotetext{
${ }^{20}$ Monzer Kahf, Waqf and Its Sociopolitical Aspects, lihat www.kahf.net/papers.html
}

wakaf harus melaporkan proses pengelolaan dananya kepada umat dalam bentuk audited financial report.

Untuk mengelola wakaf jenis apapun dibutuhkan nazhir yang profesional. Hal ini disebabkan tanggung jawab dan kewajiban memelihara, menjaga, mengembangkan wakaf, serta menyalurkan hasil atau manfaat dari wakaf kepada sasaran wakaf berada di tangan para nazhir. Menurut Undang-Undang Nomor 41 Tahun 2004 Tentang Wakaf, nadzir bertugas: (a) Melakukan pengadministrasian harta benda wakaf; (b) Mengelola dan mengembangkan harta benda wakaf sesuai dengan tujuan, fungsi, dan peruntukannya; (c) Mengawasi dan melindungi harta benda wakaf; (d) Melaporkan pelaksanaan tugas kepada Badan Wakaf Indonesia. ${ }^{21}$

Potret nadhir menurut survei CRSC memperlihatkan hanya $16 \%$ yang mengelola wakaf secara full time sedangkan mayoritas nadhir yaitu $86 \%$ mengakui tugas sebagai nadhir merupakan pekerjaan sampingan. Dari aspek profesi utama, nadhir terdiri dari PNS $33 \%$,petani/ nelayan $26 \%$, guru/ dosen $16 \%$ usahawan $10 \%$ pengurus mesjid $6 \%$ karyawan BUMN $6 \%$ dan politisi, Polri/ TNI dan karyawan swasta masing-masing $1 \% 23 .{ }^{22} \mathrm{Hal}$ ini tentu sangat berdampak pada pengelolaan wakaf yang kurang memberikan konstribusi yang nyata bagi masyarakat.

Paradigma pengelolaan wakaf secara mandiri, produktif dan tepat guna dalam membangun sebuah peradaban masyarakat yang sejahtera sesungguhnya telah dicontohkan oleh Nabi Muhammad SAW ketika memerintahkan Umar bin Khattab agar mewakafkan sebidang tanahnya di Khaibar. Perintah Nabi tersebut sangat singkat, yakni: "Tahanlah (wakafkan) pokoknya (tanahnya) dan sedekahkan hasilnya" 23 Berdasarkan hadits ini, harta wakaf harus diupayakan memberikan konstribusi yang berkesinambungan bagiumat. dengan demikian

\footnotetext{
${ }^{21}$ Pasal 11 Undang - Undang Republik Indonesia Nomor 40 Tahun 2004 Tentang Wakaf.

${ }^{22}$ Seperti di kutip Tuti A Najib dan Ridwan alMakassari, Wakaf Tuhan dan Agenda

Kemanusiaan, (Jakarta: CRSC, 2006), h. 96-97

${ }^{23}$ Nawawi, Syarah Shahih Muslim (Kairo: Sya'b, t.t) , Juz.VI, h. 21
} 
hasilnya benar-benar dapat dipergunakan untuk mewujudkan kesejahteraan umat.

\section{Kesimpulan}

Wakaf adalah salah satu instrument yang ditawarkan syariah untuk meningkatkan tingkat ekonomi dan kesejahteraan masyarakat. Pengembangan wakaf di Indonesia masih dominan pada wakaf untuk pembangunan tempat-tempat ibadah, sementara pengelolaan

\section{DAFTAR ISI}

Abdul Ghofur Anshori, Hukum dan Praktik Perwakafan di Indonesia, Pilar Media. Yogyakarta, 2005.

Agustianto, WakafTunai Dalam Hukum Positif dan Prospek Pemberdayaan Ekonomi Ssyari'ah, Makalah

Al-Syathibi, Abu Ishaq, Al-Muwafaqat fi UshulalSyari'ah, Beirut: Dar al-Ma'rifah, 1973

Al-Kabisi, Muhammad Abid Abdullah, Hukum Wakaf, Jakarta: Penerbit Iman, 2004.

Badan Wakaf Indonesia, Database dan Potensi Wakaf, publikasi di http://bwi.or.id/index. Akses 24 Februari 2011.

Dahlan, Abdul Azis, Ensiklopedi Hukum Islam, Jakarta: PT. Ichtiar Baru Van Hoeve, 2003.

Direktorat Pemberdayaan Wakaf, Direktorat Jenderal Bimbingan Masyarakat Islam, Paradigma Baru, Wakaf, 2006.

Mannan, M.A, Sertifikat Wakaf Tunai, Jakarta: UI Press, 2001

Muslim Ibn al-Hujjaj, Al-Jami' as-Sahih, Beirut: Dar al-Fikr, tt, V: 73 “Bab Mā Yulhaqu alInsān min as-Sawab Ba'da wa Fatihi. wakaf untuk proyek peningkatan ekonomi atau pengentasan kemiskinan, persentasenya masih sangat minim. Untuk optimalisasi pengelolaan wakaf, posisi nadzir sangat signifikan karena terkait langsung keberhasilan pengelolaan wakaf. Karenanya profesonalisme seorang nadzir merupakan kebutuhan, tentu disamping adanya sosialisasi secara menyeluruh untuk merubah paradigma tentang wakaf agar tidak terikat dengan teks fiqh.

Muhammad ibn al-Bukhari, Shahih al-BukhariBeirut Dar al-Fikr, 1981 M/1401 H, III: 185., “Kitab asy-Syurūt fī al-Wakaf." Hadis riyawat Bukhari dari Qutaibah ibn Sa'ad dari Muhammad ibn Abdullah al-Anshari dari ibn 'Aun dari Nafi' dari ibn 'Umar Hadis ini sanadnya muttasil

Muhammad Daud Ali, Sistem Perekonomian Islam, Zakat dan Wakaf, UI Press, Jakarta, 1988.

M. Kahf, Waqf and Its Sociopolitical Aspects, www.kahf.net/papers.html

Nawawi, Syarah Shahih Muslim (Kairo: Sya'b, t.t) , Juz.VI.

Republika, 27 Oktober 2011

Sayyid Sabiq, Fiqh Sunnah, Beirut, Dar alFikri,1980

Tuti A Najib dan Ridwan al-Makassari, Wakaf Tuhan dan Agenda Kemanusiaan, Jakarta: CRSC, 2006.

Uswatun Hasanah dalam Kata Pengantar Buku Munndzir Qahaf, Manajemen Wakaf Produktif, Jakarta: Khalifa, 2005.

Undang-Undang Republik Indonesia Nomor 41 Tahun 2004 tentang wakaf

Zuhaili, Wahbah, Al-Fighal-Islamiywa 'Adillatuhu. Mesir: Dar al-Fikr al-Mu’ashir, 1985. 